UDK 582.711.714:577.164.2

543.42:577.164.2

\title{
DETERMINATION OF VITAMIN C IN FLOWERS OF SOME BOSNIAN CRATAEGUS L. SPECIES \\ Određivanje vitamina $\mathrm{C}$ u cvjetovima nekih bosanskohercegovačkih vrsta roda Crataegus L.
}

\author{
Azra Tahirović1 , Amira Čopra - Janićijević², Nedžad Bašić ${ }^{1}$, Lejla Klepo², \\ Mirel Subašić ${ }^{1}$
}

\begin{abstract}
Vitamin $\mathrm{C}$ or ascorbic acid content has been determinated by spectrophotometric method and titrimetric method in flowers of some Bosnian hawthorns (Crataegus L). species. Spectrophotometric method used in this study was based on the kinetic reaction between Vitamin $\mathrm{C}$ and methylene blue. Measurements were carried out at absorption maximum, $\lambda_{\max }=665 \mathrm{~nm}$. We found that the lowest content of vitamin $\mathrm{C}$ was $617.07 \mathrm{mg} / 100 \mathrm{~g}$ of dry sample in flowers of the C. microphylla, and the highest level of Vitamin C was found in the C. monogyna (1104 mg/100 g of dry sample) flowers. Recoveries of the results obtained by the spectrophotometric method were 94 $\%-100 \%$ with relative standard deviation (RSD) values from $4.5 \%-6.7 \%$.

Obtained results shown that flowers of investigated Crataegus L. species are good source of vitamin $\mathrm{C}$.
\end{abstract}

Key words: ascorbic acid, Crataegus, hawthorns, flowers, spectrophotometry, Vitamin C

\section{INTRODUCTION - Uvod}

Vitamins are organic nutrients that are required in small quantities for a variety of biochemical functions. They generally can not be synthesized by the human body and must be supplied in diet (MARCUS AND COULSTON 2001). Vitamin C (ascorbic acid) is a water soluble antioxidant which is found in variable quantities in fruits and vegetables (SzETO ET AL., 2002; IGBAL ET AL., 2004). Vitamin C is required for the production of collagen in the connective tissue, teeth and bones. It is a strong antioxidant which helps protect against cancer, heart diseases and stress (ENGLARD AND

\footnotetext{
${ }^{1}$ Faculty of Forestry University of Sarajevo

${ }^{2}$ Faculty of Natural Sciences and Mathematics, University of Sarajevo
} 
SEIFTER, 1986; PEREZ-RIUZ ET AL., 2001). Its antioxidant activity can protect us from damaging effects of air pollution and radiation (FREDERICK AND KLEMER, 1971).

In diet, it is also needed to prevent scurvy. According to World Health Organization recommended daily amount of Vitamin $\mathrm{C}$ are 45-50 $\mathrm{mg}$ (WHO/FAO, 2004). In recent years, plants as natural sources of different phytochemicals as food or medicinal supplements become more important in scientific researches.

In Bosnia and Herzegovina chemical composition of hawthorn is insufficiently investigated. Crataegus L. is a polymorphic genus from Rosaceae family, widespread in temperate regions of the Northern Hemisphere. Mostly, its species are shrubs or small trees growing to 5-15 $\mathrm{m}$ tall with pome red fruit and thorny branches. Only a few researchers studied populations of Crataegus from Bosnia and Herzegovina (BECK, 1927; MALÝ, 1919, 1940; FUKAREK, 1974; JANJIĆ, 1998, 2002). According to recent investigations, four autochthonic species of Crataegus and their few hybrid complexes can be found in Bosnia and Herzegovina (BAŠıć, 2004). One of the most abundant species, with highly wide ecological amplitude, is Crataegus monogyna Jacq. Contrary, C. microphylla Koch subsp. malyana (CHRISTENSEN AND JANJIĆ, 2006) and $C$. rhipidophylla Gand. are the species which are recently included on the list of Flora of Bosnia and Herzegovina. According to JANJIĆ AND CHRISTENSEN (2006) C. microphylla subsp. malyana is endemic to Bosnia and Herzegovina and it represents isolated enclaves at the end of its west areal. The fourth autochthonic species C. laevigata (Poiret) DC, which grows on meadows in the north, was not a subject of our investigations. All previously mentioned species are joined to ser. Crataegus, which comes inside sect. Crataegus by CHRISTENSEN (1992). Since interspecies breedings are frequent in hawthorns, in this study we also analysed and species $C$. $\times$ subsphaericea Gand., originated from $C$. rhipidophylla $\times C$. monogyna (JANJIĆ, 2002) and C. macrocarpa originated from C. rhipidophylla $\times$ C. monogyna.

Some Crataegus species are traditionally used as medicinal plants with many health benefits. Dried flowering tops, flowers, leaves and fruits are used as crude drugs. The species most used medicinally are $C$. monogina and $C$. laevigata (AMMNON AND HANDEL, 1981). The monographs "Hawthorn Leaf and Flowers" and "Hawthorn berries" are included in the European Pharmacopoeia.

Preparations of hawthorn including leaf, flowers are have been used traditionally in minor forms of coronary heart disease (HANSEL ET AL., 1992, VEVERIS ET AL., 2004), heart failure and cardiac arrhythmia (ZAPIE JUN, 2001). The extract is clinically effective in reducing blood pressure and total plasma cholesterol (HANACK AND BRUCKEL, 1983). The main biological active substances detected in the medicinal vegetal raw materials of hawthorn are flavonoids and their glycosides, oligomeric procyanidins, catechines and phenolic acids (CUI ET AL., 2006; BAHORUN ET AL., 1994; BAHORUN ET AL., 2003; SWEDSTROM ET AL., 2006; URBONAVICIUTE ET AL., 2006).

Different analytical methods were used in the determination of ascorbic acid including titrimetric analysis (AOAC, 2005), spectroscopy (ARAYA ET AL., 1998; BAJAJ AND KAUR, 1981; ZHENG ET AL., 2005), chromatography (EIRENMILLER, 2008, BuSHWAY ET AL., 1998) and electroanalysis (OGUNLESI ET AL., 2010). 
In this study we investigated content of vitamin $\mathrm{C}$ in flowers of selected Crataegus species including two hybrids collected from different localities on mountain Trebević in Sarajevo region. In the determination of AA two methods of analysis were used: titrimetric and spectrophotometric determination in order to compare obtained results. According to our knowledge there are no previous reports regarding content of vitamin $\mathrm{C}$ in flowers of selected Crataegus species and hybrids from territory of Bosnia and Herzegovina.

Assessment of phytochemicals such as Vitamin $\mathrm{C}$ of the naturally growing Crataegus species is significant for evaluation of the quality of local raw hawthorn material and for the rational exploitation of herbal resources. This work will also give better view on applicability of selected spectrophotometric method in the determination of AA in flowers of Crataegus species.

\section{MATERIALS AND METHODS - Materijali i metode}

\section{Plant material - Biljni materijal}

Hawthorn flowers material was collected from natural populations on several localities on a mountain Trebević, near Sarajevo during June and July 2012 (Table 1). Identification and taxonomic determination of the analysed species was carried out with comparative-morphological analysis.

The fresh flowers were sorted out and dried in the drying room with ventilation at ambient temperature for 15 days. All voucher specimens are deposited in the, Faculty of Forestry, Department of Ecology, Botanic Laboratory Herbarium.

Table 1. Investigated Crataegus species and sampling localities

Tabela 1. Ispitivane vrste glogova i mjesta uzorkovanja

\begin{tabular}{|c|l|l|}
\hline Number & Hawthorn species & Localities \\
\hline 1. & C. monogyna & Dobre vode \\
\hline 2. & C. rhipidophylla & Zlatište \\
\hline 3. & C. x macrocarpa & Dobre vode \\
\hline 4. & C. $\times$ subsphaericea & Dobre vode \\
\hline 5. & C. microphylla & Ravni \\
\hline
\end{tabular}

\section{Reagents - Reagensi}

L(+)-ascorbic acid; starch (Kemika) and methylene blue were supplied by Merck (Germany). Glacial acetic acid and potassium iodide were purchased from Semikem (Bosnia and Herzegovina). Starch was obtained from Carlo-Erba (Spain) and iodine from Kemika (Croatia). All chemicals used in the work were of analytical grade. 


\section{Preparation of solution - Priprema rastvora}

Iodine solution $\left(0.005 \mathrm{~mol} \mathrm{~L}^{-1}\right)$. Potassium iodide $(2.0 \mathrm{~g})$ and iodine $(1.3 \mathrm{~g})$ were dissolved in $100 \mathrm{~mL}$ distilled water. This solution is diluted ten times. The concentration of prepared iodine solution was more accurately determinated by titration with a standard solution of AA.

Starch indicator solution $(0.5 \%)$. Soluble starch $(0.25 \mathrm{~g})$ was added to $50 \mathrm{~mL}$ of near boiling distilled water. It was stirred to dissolve and cooled before use.

Stock solution of ascorbic acid containing $0.1 \mathrm{molL}^{-1}$ of AA was prepared by dissolving appropriate amount of ascorbic acid in distilled water and stored in a glass stopped bottle at $4^{\circ} \mathrm{C}$ in the dark. Solutions of variable concentrations were prepared by diluting the stock standard solution in water before use.

Methylene blue solution $\left(0.4 \mathrm{mmolL}^{-1}\right)$ was prepared by dissoloving $0.0128 \mathrm{~g}$ of methylene blue in $100 \mathrm{~mL}$ distilled water.

\section{Preparation of samples - Priprema uzoraka}

Five samples of selected Crataegus L. species were used for the determination of ascorbic acid. For AA determination, $2.5 \mathrm{~g}$ of flower samples were coarsely powdered and glacial acetic acid $(2 \mathrm{~mL})$ was added. The mixture was stirred for about 20 minutes and rapidly filtrated using a suction pump and Buchner funnel. After that, the volume of the sample is made up to $100 \mathrm{~mL}$ with distilled water. The samples were analyzed with two methods, spectrophotometric and titrimetric in very short time after sample preparation.

\section{Spectrophotometric determination AA - Spektrofotometrijsko odredivanje AA}

The spectrophotometric study was carried out by UV/VIS portable Spectrometer (Shimadzu, Japan) to determine the amounts of AA in the samples. Fifty microliters of a sample solution was mixed with $125 \mu \mathrm{L}$ of $\mathrm{MB}\left(\mathrm{c}=0.4 \mathrm{mmolL}^{-1}\right)$ solution and diluted up to $10 \mathrm{~mL}$ with distilled water. Decrease of absorption was measured at $\lambda_{\max }=665 \mathrm{~nm}$. All analysis were carried out in triplicates. Results are expressed in $\mathrm{mg}$ of ascorbic acid per $100 \mathrm{~g}$ of dry sample.

\section{Reaction mechanism - Reakcioni mehanizam}

Methylene blue $\left(\mathrm{MB}^{+}\right)$is a water soluble dye molecule. Under acidic conditions it can be easily reduced to colourless hydrogenated molecule leucomethylene blue $\left(\mathrm{LMB}^{+}\right)$by ascorbic acid as it shown in Figure 1. The stoichiometry of the reaction was $1: 1$. 
<smiles></smiles>

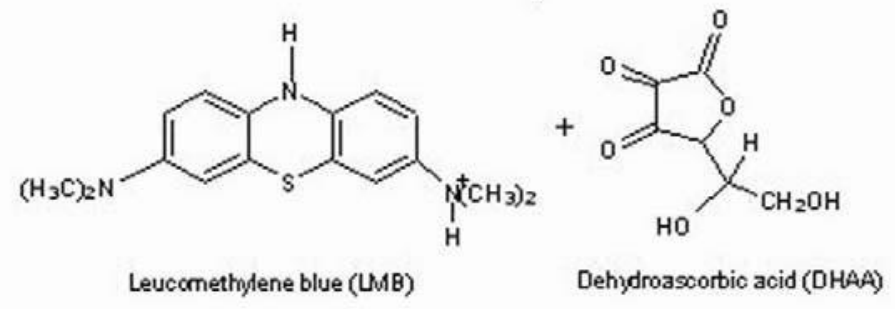

Figure 1. Reaction mechanism of MB with AA

Slika 1. Reakcioni mehanizam MB sa AA

\section{Preparation of calibration curve-Priprema kalibracione krive}

A stock solution of AA $\left(0.1 \mathrm{molL}^{-1}\right)$ was used for preparation of working solutions in concentration range from $5 \cdot 10^{-6}$ to $1.25 \cdot 10^{-4} \mathrm{molL}^{-1}$. Working solutions of AA were prepared immediately before use in order to prevent loss of the analyte due to its instability at low concentrations.

\section{Titration conditions - Titracijski uslovi}

Titrimetric determination of AA was done according to the following procedure: $10 \mathrm{~mL}$ of the filtrate, $50 \mathrm{~mL}$ of distilled water and $1 \mathrm{~mL}$ of $0.5 \%$ starch solution were mixed and immediately titrated to the end-point with the standardized $0.005 \mathrm{molL}^{-1}$ iodine solution using $0.5 \%$ starch. The titrations were repeated in triplicates and blank determinations were carried out followed the above procedure using $10 \mathrm{~mL}$ of distilled water instead of the filtrate. Results are expressed in $\mathrm{mg}$ of ascorbic acid per $100 \mathrm{~g}$ of dry sample. 


\section{RESULTS AND DISCUSSION - Rezultati i diskusija}

Ascorbic acid is ubiquitous antioxidant present in animal and plant cells (DAVEY ET AL., 2000). It plays a key role in the detoxification of activated oxygen acting as an antioxidant either by reducing superoxide, hydrogen peroxide and hydroxyl radicals or by quenching singlet oxygen (FOYER ET AL., 1991).

In this work flowers of selected Crataegus species were investigated regarding their content of ascorbic acid. Contents of ascorbic acid were determined in the flowers by spectrophotometric and titrimetric methods. Titrimetric method based on iodimetry was used in the analysis of plant materials. Generally, titrimetric methods are used frequently when high concentration of AA is considered. Extensive review about titrimetric methods used in plant analysis for the determination of Vitamin C is given by ARYA ET AL. (2000).

In order to understand relationships of nutrient intake and human health, an accurate and specific determination of the nutrient content of plants is extremely important. For these reasons great caution should be exercised in the employment of the methods that have been developed for the analysis of specific plant tissue types (DAVEY ET AL., 2000). Several spectrophotometric methods have been reported in the determination of AA in plants material (BAJAJ AND KAUR 1981; KLEIN AND PERRY, 1982). Spectrophotometric method used in this study is based on the measurement of decreasing of the absorption intensity of coloured methylene blue $\left(\mathrm{MB}^{+}\right)$. The method involves reduction of coloured methylene blue $\left(\mathrm{MB}^{+}\right)$dye by ascorbic acid where as a result of the reaction colourless leucomethylene blue $\left(\mathrm{CMB}^{+}\right)$product is formed (MOWRLY AND OREGON, 1999). Measurements were carried out at absorption maximum, $\lambda_{\max }=665 \mathrm{~nm}$. This method is previously used in the determination of AA in hawthorn fruits under optimized conditions (TAHIROVIĆ ET AL., 2012). The reaction system is a basis for indirect spectrophotometric determination of AA when added in increasing amount, consume $\mathrm{MB}^{+}$and decreasing the concentration of $\mathrm{MB}^{+}$. The absorbance is found decrease linearly with increasing in concentration of AA. The calibration graph was drown by plotting the absorbance against concentration of AA, and the amount of AA was obtained from the calibration curve. Obtained calibration curve was linear in a concentration range of $5 \cdot 10^{-6}-1.25 \cdot 10^{-4} \mathrm{molL}^{-1}$ with following parameters: $\mathrm{a}=0.2449, \mathrm{~b}=-131.82$, and correlation factor of $\mathrm{r}^{2}=0.9907$

The iodimetric method was used as a reference method for comparison of the obtained results (Table 2). The results were expressed as $\mathrm{mg}$ ascorbic acid per $100 \mathrm{~g}$ of dry sample (DW). 
Table 2. Content of AA (mg/100 g) in flowers of five samples of Crataegus L. species determined by spectrophotometric and titrimetric methods. Results are expressed as mean $\pm \mathrm{SD}(\mathrm{n}=3)$

Tabela 2. Sadržaj AA (mg/lo0g) u cvjetovima pet uzoraka glogova određene spektrofotometrijskom $i$ titrimetrijskom metodom. Rezultati su izraženi kao srednja vrijednost $\pm S D(n=3)$

\begin{tabular}{|c|c|c|c|}
\hline Species & $\begin{array}{c}\text { Titrimetry } \\
(\mathbf{m g} / \mathbf{1 0 0} \mathbf{g})\end{array}$ & $\begin{array}{c}\text { Spectrophotometry } \\
(\mathbf{m g} / \mathbf{1 0 0} \mathbf{g})\end{array}$ & Recovery(\%) \\
\hline $\begin{array}{c}\text { C. monogyna } \\
\text { (Dobre vode) }\end{array}$ & $1108 \pm 6.47$ & $1104 \pm 61.77$ & 99.40 \\
\hline $\begin{array}{c}\text { C. rhipidophylla } \\
\text { (Zlatište) }\end{array}$ & $962.47 \pm 6.70$ & $925 \pm 62$ & 100.0 \\
\hline $\begin{array}{c}\text { C. microphylla } \\
\text { (Ravni) }\end{array}$ & $658.31 \pm 4.79$ & $617.07 \pm 37.02$ & 94.00 \\
\hline $\begin{array}{c}\text { C. } \times \text { macrocarpa } \\
\text { (Dobre vode) }\end{array}$ & $857.13 \pm 32.97$ & $854.37 \pm 38.87$ & 99.60 \\
\hline $\begin{array}{c}\text { C. } \times \text { subsphaericea } \\
\text { (Dobre vode) }\end{array}$ & $1108.5 \pm 16.7$ & $1103 \pm 61.42$ & 99.50 \\
\hline
\end{tabular}

The content of ascorbic acid determined by spectrophotometric method ranged between 617.07 and $1104 \mathrm{mg} / 100 \mathrm{~g}$ of dry sample for all investigated species (Table 2). The highest content of ascorbic acid was measured in flowers of $C$. monogyna and C. $\times$ subsphaericea, $1104 \mathrm{mg}$ and $1103 \mathrm{mg} / 100 \mathrm{~g}$ respectively. The lowest content of ascorbic acid was found in flowers of C. microphylla $(617.07 \mathrm{mg} / 100 \mathrm{~g})$. Content of ascorbic acid in a hybride C.× macrocarpa $(854.37 \mathrm{mg} / 100 \mathrm{~g})$ was very close to content of AA in C. rhipidophylla $(925 \mathrm{mg} / 100 \mathrm{~g})$.

These results on determination of ascorbic acid were in well agreement with the results obtained by titrimetric method. They indicate that spectrophotometric method based on methylene blue can be used as an alternative to titrimetric method in determination of AA content in Crataegus flowers. Recovery of the results obtained by spectrophotometric method was $94 \%-100 \%$ with RSD values ranging from $4,5 \%$ to $6,7 \%$. Generally, some lower results were obtained with the spectrophotometric method suggesting that minor matrix effect could be present.

Obtained results show that flowers of Crataegus species and their investigated hybrids are very rich in content of ascorbic acid. Generally, the ascorbic acid content in flowers of C. monogyna are much higher than those found by some researchers e.g. EGEA ET AL. (2010); BARROS ET AL. (2011). Among investigated species some of them, such as C. microphylla, have lower AA content than C. monogyna. To the best of our knowledge, there are no literature data concerning content of AA in flowers of $C$. rhipidophylla and their hybrids, $C . \times$ subsphaericea and $C . \times$ macrocarpa as well as $C$. microphylla so that comparison of our results with the results other authors was not possible. Different researches found that content of AA in C. monogyna fruits is much lower than in flowers (TAHIROVIĆ, ET AL., 2012; BARROS ET AL., 2011). According to TAHIROVIĆ ET AL. (2012) content of ascorbic acid ranged between 102.25 and 142.16 
$\mathrm{mg} / 100 \mathrm{~g}$ of dry sample for C. monogyna. Content of AA in fruits of C. rhipidophylla and $C . \times$ subsphaericea were similar $142,8 \mathrm{mg} / 100 \mathrm{~g}$ sample while $C$. microphylla had highest content of AA in fruits $(229 \mathrm{mg} / 100 \mathrm{~g}$ sample). BAROS ET AL. (2011) investigated content of AA in unripe, ripened and over ripened fruits of $C$. monogyna. They found that content of AA in fruits vary from $220 \mathrm{mg}-28.40 \mathrm{mg} / 100 \mathrm{~g}$ of dry sample during different stages of fruits growing. The highest content of AA was found in flowers $(408 \mathrm{mg} / 100 \mathrm{~g}$ dry sample) and ripened fruits $220 \mathrm{mg} / 100 \mathrm{~g}$.

Similar observation was noticed by RASANU ET AL. (2005) who investigated content of AA in flowers and fruits of apple, apricot and cherry in different growing stages. The authors found that content of AA in flowers of apple, apricot and cherry was for 6, 7 and 13 times higher than in their fruits respectively. Obtained results will help to understand better medicinal and nutritional impact of the investigated species. Since some of the investigated plants are not used as official medicinal plants, these results suggest that some further investigations of autochthonic Bosnian Crataegus species in their application as a valuable source of vitamin $\mathrm{C}$ in pharmaceutical industry is needed.

\section{CONCLUSIONS - Zaključci}

- Spectrophotometric method based on reaction of methylene blue and ascorbic acid was used in determination of AA content in flowers of three Crataegus species and two hybrids native in Bosnia and Herzegovina. Obtained results were compared with iodimetric determination and good agreement between results was obtained.

- In this work first data were given for content of ascorbic acid in flowers of $C$. rhipidophylla, C. microphylla C.× subsphaericea and C. macrocarpa of Bosnian species.

- The highest content of vitamin $\mathrm{C}$ was found in C. monogyna, while the lowest content of vitamin $\mathrm{C}$ was found in C. microphylla.

- All investigated hawthorn species had high contents of vitamin $C$ where very close values are noticed in C. monogyna, C.× subsphaericea and C. rhipidophylla, C. $\times$ macrocarpa.

- Generally, the content of AA in hawthorn flowers is much higher than those in hawthorn fruits found by other investigators.

- According to our best knowledge, this is the first time that content of ascorbic acid was investigated in flowers of some Bosnian Crataegus species.

- Obtained results will help to better understand nutritional and medicinal impact of the investigated species. The results can be also useful for pharmaceutical industry in development of new medicinal preparations. 


\section{REFERENCES - Literatura}

Ammon, H.P.T., Handel, M. (1981): Crataegus, toxicology and pharmacology. Parts IIII. Planta Medica, 43: 1050-20, 209-39, 313-22.

AOAC International, official methods of analysis, $18^{\text {th }}$ ed., AOAC International, Arlington, VA, 2005.

ARAYA, S. P., MAHAJAN, M., JAIN, P. (1998): Photometric methods for the determination of vitamin C. Analytical Sciences, 14: 889-894.

ARAYA, S. P., MAHAJAN, M., JAIN, P. (2000): Non-spectrophotometric methods for the determination of Vitamin C. Analytica Chimica Acta, 417: 1-14.

Bahorun, T., Trotin, F., Pommery, J., Vasser, J., Pinkas, M. (1994): Antioxidant activities of Crataegus monogyna Extracts. Planta Medica, 60: 323-328.

Bahorun, T., Aumjand, E., Ramphul, H., Ryeha, M., luximon-Ramma, A., Trotin, F. (2003): Phenolic constituents and antioxidant capacities of Crataegus monogyna (Hawthorn) callus extracts. Nahrung, 47 (3): 191-8.

BAJAJ, K.L., AND KAUR, G. (1981): Spectrophotometric determination of L-ascorbic acid in vegetable and fruits. Analyst, 106(1258): 117-20.

Barros, L., CARvalho, A.M., Ferreira, C.F.R. (2011): Comparing the composition of bioactivity Crataegus monogyna flowers and fruits used in folk medicine. Phytochemical analysis, 22(2), 181-8.

BAšıć, N. (2004): Morfološko-taksonomska istraživanja glogova (Crataegus L.) na području Bosne i Hercegovine. Magistarski rad. Sarajevo.

BeCK, G. (1927): Flora Bosne, Hercegovine i oblasti Novoga Pazara. III. Choripetalae (Kaj): 169-172. Beograd-Sarajevo.

Bushway, R. J., KING, J. M., PerkINS, B. M., Krishnan, M. (1988): High-performance liquid chromatographic determination of ascorbic acid in fruits, vegetables and juices. Journal of Liquid Chromatography, 11: 3415 - 3423.

Christensen, K. I. (1992): Revision of Crataegus Sect. Crataegus and Notosect. Crataegineae (Rosaceae-Maloideae) in the old world. Systematic Botany Monographs, 35: 1-199.

Christensen, K. I., JANJić, N. (2006): Taxonomic notes on European taxa of Crataegus (Rosaceae). Nordic Journal of Botany, 24: 143-147.

Cul, T., Nakamura, K., Tian, S., Kayahara, H., Tian, Y. L. (2006): Polyphenolic content and physiological activities of Chinese hawthorn extracts. Bioscience Biotechnology and Biochemistry, 70 (12): 2948-56.

Davey, M. W., Van Montagu, M., Inzé, D., Sanmartin, M., Kanellis, A., Smirnoff, N., Benzie, I. J. J., Strain, J. J., Favell, D., Fletcher, J. (2000): Plant L-ascorbic 
acid: chemistry, function, metabolism, bioavailability and effects of processing. Journal of the Science of Food and Agriculture, 80, 825-860.

Egea, I., Sanchez-Bel, P., Ramojaro, F., Pretel, M. T. (2010): Six edible wild fruits as potential antioxidant additives or nutritional supplements. Plant Foods for Human Nutrition, 65:121-129.

EITENmilleR, R. R., YE L., LANDEN, W. O. (2008): Vitamin analysis for the health and food sciences. CRC Press, Taylor \& Francis Group, UK, 231-274.

ENGLARD, S., SEIFTeR, S. (1986): The biochemical functions of ascorbic acid. Annual Review of Nutrition, 6: 365-406.

Foyer, C.H., Lelandias, M., EdWARds, E.A., MullineauX, P. M. (1991): Current topics in plant physiology, 6, ASPP, Rockville, 131.

FREDERIK, R. AND KLENNER, M.D. (1971): Observation on the dose of vitamins and administration of ascorbic acid. Journal of Applied Nutrition, 23: 2-3

FUKAREK, P. (1974): Neke vrste drveća i grmlja koje su pogrešno navedene u Flori Bosne i Hercegovine i susjednih krajeva. ANU BiH-Radovi LIV, Odjeljenje prirodno-matematičkih nauka, 15: 45-60.

HANACK, T., BRUCKEL, M. H. (1983): The treatment of mild stable forms of angina pectoris using crategutt novo. Therapiewoche, 33: 4331-4333.

Hansel, R., Keller, K., Rimpler, H., Schneider, G. (1992): Hagers Handbuch der Pharmazeutischen Praxis, Vol. 4, Drogen A-D, 5th ed., Springer, Berlin, Heidelberg: 1040-1062.

IGBAL, K, KHAN, A., KHATAK, M.A.K (2004): Biological significance of ascorbic acid (Vitamin C) in human health - A review. Pakistan Journal of Nutrition, 3(1): 5-13.

JANJIĆ, N. (1998): Neki zanimljivi dendrološki nalazi iz sarajevskog područja. Radovi Šmarskog Fakulteta Univerziteta u Sarajevu, 28(1): 85-103.

JANJIĆ, N. (2002): Nova kombinacija u lepezolisnog ili krivočašičnog gloga, Crataegus rhipidophylla Gand. (Rosaceae). Radovi Šumarskog Fakulteta Univerziteta u Sarajevu, 32(1): 1-7.

KLEIN, B.P., AND PERRY, A.K. (1982): Ascorbic acid and vitamin A activity in selected vegetables from different geographical areas of the United States. Journal of Food Science, 47: 941-945.

MaLÝ, K. (1919): Prilozi za floru Bosne i Hercegovine 5 i 6. Glasnik Zemaljskog Muzeja BiH, Sarajevo, 31: 61-92.

MALÝ, K. (1940): Notizen zur Flora von Bosnien-Herzegovina. Glasnik Zemaljskog Muzeja BiH, Sarajevo, 52: 21-46.

Marcus, R. AND Coulston, A.M. (2001): The Vitamins: In: Goodman and Gilmans The Pharmacological Basis of Therapeutics. $10^{\text {th }}$ ed., Hardman J.G. and Limbirb LE (eds), Mcgraw-Hill Co., USA, pp: 1767-1771. 
MoWry, S., ORGEN, P. J. (1999): Kinetics of methylene blue reduction by ascorbic acid, Journal of Chemical Education, 76(7): 970-974.

Ogulnesi, M., Okiel, W., Azeez, L., Obakachi, V., Osunsanmi, M., Nkenchor, G. (2010): Vitamin $C$ contents of tropical vegetables and foods determined by voltammetric and titrimetric methods and their relevance to the medicinal uses of the plants. International Journal of Electrochemical Science, 5: 105-115.

Perez-Ruiz, T., martinez-Lozano, K., Tomas, V., Penol, J. (2001): Fluorimetric determination of total ascorbic acid by a stopped flow mixing technique. Analyst, 126, 1436-1439.

Rasanu, N., Magearu, V., Matel, N., Soceanu, A. (2005): Determination of Vitamin C in different stages of fruits growing. Analele Universitatatii din BucurestiChimie, Annual XIV, Vol. 1-11: 167-172.

Svedstrom, U., Vuorela, U.H., Kostiainen, R., Laakso, I., Hiltunen, R. (2006):

Fractionation of polyphenols in hawthorn into polymeric procyanidins, phenolic acids and flavonoids prior to high-performance liquid chromatographic analysis. Journal of Chromatography, 1112: 103-111.

Szeto, Y.T., Tomlinson, B., BenZIE, I.F. (2002): Total antioxidant and ascorbic acid content of fresh fruits and vegetables: implications for dietary planning and food preservation. The British Journal of Nutrition, 87 (1): 55-9.

TahiRović, A., Čopra-JanićIJeVIć, A., BašIĆ, N., VIDIC, D., KLePo L., Delić, D. (2012):

Determination of Vitamin $C$ in some Bosnian Crataegus L. species by spectrophotometric method. Works of Faculty of Forestry University of Sarajevo, 42(1): 43-55.

Urbonaviciute, A., Jakstas, V., Kornisova, O., JanUlis, V., Maruska, A. (2006): Capillary electrophoretic analysis of flavonoids in single-styled hawthorn (Crataegus monogyna Jacq.) ethanolic extracts. Journal of Chromatography, 1112: 339-344.

VeVeris, M., KoCH, E., ChatTerJee S.S. (2004): Crataegus special extract WS®1442 improves cardiac function and reduce infarct size in a rat model of prolonged coronary ischemia and reperfusion. Life Science, 74: 1945-1955.

WHO/FAO (2004): Vitamin and mineral requirements in human nutrition. Second edition, World Health Organisation and Food and Agricultural Organisation of the United Nations, Sung-Fung, China, Chapter 7, 130-139.

ZAPIE JAN, G. (2001). Clinical efficacy of Crataegus extracts WS®1442 in congestive heart failure NYHA class II. Phytomedicine, 8: 262-266.

Zeng, W., MARTINUZZI, F., MAC Gregor, A. (2005): Development and application of a novel UV method for the analysis of ascorbic acid. Journal of Pharmaceutical and Biomedicine Analysis. 36(5): 1107-1111. 


\section{SAŽETAK}

U studiji su prikazani rezultati određivanja vitamina $\mathrm{C}$ u cvjetovima odabranih bosanskohercegovačkih vrsta glogova (Crataegus L). U ispitivanjima korištene su tri vrste i dva hibrida glogova i to: C. monogyna, C. rhipidophylla, C. microphylla, C.× macrocarpa $i$ C. $\times$ subsphaerice.

Određivanje vitamina $\mathrm{C}$ u biljnim uzorcima je vršeno primjenom spektrofotometrijske metode, zasnovane na kinetičkoj reakciji askorbinske kiseline (AA) sa metilenskim plavim $\left(\mathrm{MB}^{+}\right)$. Mjerenja intenziteta apsorpcije su vršena na apsorpcionom maksimumu, $\lambda_{\max }=665 \mathrm{~nm}$. U studiji je korištena i poredbena titrimetrijska metoda analize sadržaja vitamina $\mathrm{C}$ zasnovana na jodimetrijskom određivanju uz indikator skrob.

Sadržaj vitamina $\mathrm{C}$ u ispitivanim uzorcima cvjetova različitih vrsta glogova se kretao u rasponu 617,07 - $1104 \mathrm{mg}$ vitamina C na $100 \mathrm{~g}$ suhog uzorka cvijeta. Dobivene vrijednosti iskorištenja (recovery) za spektofotometrijsku metodu, su se kretale od $94 \%$ do $100,0 \%$, dok je vrijednost relativne standardne devijacije (RSD) iznosila 4,5\% - 6,7\% u odnosu na referentnu metodu.

Iz dobivenih rezultata određivanja sadržaja vitamina $\mathrm{C} u$ ispitivanim uzorcima cvjetova odabranih vrsta glogova može se uočiti da su sadržaji vitamina $\mathrm{C}$ u svim ispitavanim uzorcima znatno visoki. Vrste $C$. rhipidophylla, $C$. monogyna kao i njihov hybrid C.× subsphaericea imaju dosta slične vrijednosti sadržaja vitamina $C$ i veći u odnosu na druge ispitivane specije. C. macrocarpa po vrijednosti sadržaja vitamina $\mathrm{C}$ je dosta slična vrsti C. rhipidophylla. Najmanji sadržaj vitamina $C$ je određen u cvijetu endemične vrste, $C$. microphylla i u odnosu na oficijelnu ljekovitu vrstu, $C$. monogyna, manji je za približno dva puta.

$\mathrm{U}$ odnosu na prethodna istraživanja autora određivanja sadržaja vitamina $\mathrm{C} \mathrm{u}$ plodovima određenih vrsta glogova (TAHIROVIĆ ET AL., 2012), sadržaji vitamina C u plodovima i cvjetovima vrsta C. monogyna i C. microphylla se odnose obrnuto.

Dobiveni rezultati jasno ukazuju da su cvjetovi ispitivanih vrsta glogova $\mathrm{i}$ hibrida dobar izvor vitamina C. Rezultati su značajni s aspekta evaluacije kvaliteta glogova i njihove primjene u farmaceutskoj industriji. 